\title{
Sentinel Lymph Node in Melanoma - a Study Conducted in the South of Brazil
}

\section{Sentinelová uzlina u melanomu - studie provedená v jižní Brazílii}

\author{
Rovere R. K. ${ }^{,}$, Silva de Lima A. ${ }^{2}$, DeMarchi V. ${ }^{3}$, Stein C. E. ${ }^{4}$ \\ ' Department of Medical Oncology, Santo Antonio Hospital, Blumenau, Santa Catarina, Brazil \\ ${ }^{2}$ Medical Dermatologist, Private Office, Brusque, Santa Catarina, Brazil \\ ${ }^{3}$ General and Oncologic Surgeon, Santo Antonio Hospital, Blumenau, Santa Catarina, Brazil \\ ${ }^{4}$ Statistician at Fundacao Universidade de Blumenau, Blumenau, Santa Catarina, Brazil
}

\begin{abstract}
Summary
Background: The presence or absence of lymph node metastases is a very important prognostic factor for survival and recurrence in patients with cutaneous melanoma. Controversies remain among specialists about whether it is advisable or not to perform a sentinel lymph node biopsy in patients with melanoma, although it is currently supported by most standard guidelines. We performed this study to identify which patients are more prone to having a positive lymph node test result in a population with high melanoma rates in the south of Brazil. Materials and Methods: We performed the study with 62 consecutive patients who underwent sentinel lymph node biopsies from 2003 to the early months of 2015 in the city of Blumenau - Santa Catarina, Brazil. Results: Breslow thickness, ulceration, nodular subtype, and Clark level IV were associated with positive sentinel lymph node group status $(p \leq 0.05)$. Discussion: Although there is still a controversy over whether or not this procedure should be performed, most guidelines still support its application. To lower the economical and physical impact, however, it is worthwhile to determine which patients are more prone to acquiring positive lymph node at presentation and, perhaps, in the future, indicate surgery for this particular group, who could benefit most from further treatment options.
\end{abstract}

Key words

melanoma - sentinel lymph node biopsy - prognosis

\section{Souhrn}

Východiska: Přítomnost nebo neprítomnost metastáz lymfatických uzlin je nejdůležitějším prognostickým faktorem pro přežití a recidivy u pacientů s kožním melanomem. Mezi odborníky se vedou spory, zda je vhodné či nikoli provést biopsii sentinelové uzliny u pacientů s melanomem, i když v současné době je tento názor podporován většinou standardních guidelines. Provedli jsme tuto studii s cílem určit, kteří pacienti jsou náchylnější k pozitivnímu nálezu $\checkmark$ populaci s vysokou mírou melanomu na jihu Brazílie. Materiály a metody: Provedli jsme studii u 62 po sobě jdoucích pacientů, kteří podstoupili biopsii sentinelové uzliny od roku 2003 do prvních měsíců roku 2015 ve městě Blumenau, Santa Catarina, Brazílie. Výsledky: Breslow tloušt'ka, ulcerace, nodulární podtyp a stadium Clark IV byly spojeny se stavem pozitivní sentinelové uzliny $(p \leq 0,05)$. Diskuze: I když přetrvávají rozpory, zda tento postup provádět, většina guidelines tuto indikaci stále podporuje. Abychom však snižili ekonomické i fyzické náklady, je nutné pokusit se vytipovat pacienty náchylnější k výskytu pozitivních lymfatických uzlin a ty pak prípadně $v$ budoucnosti indikovat $k$ operaci. Tato specifická skupina pacientů by mohla mít z další léčby největší benefit.

\section{Klíčová slova}

melanom - biopsie sentinelové uzliny - prognóza
The authors declare they have no potential conflicts of interest concerning drugs, products, or services used in the study.

Autoři deklaruji, že $v$ souvislosti s predmětem studie nemaji žádné komerční zájmy.

The Editorial Board declares that the manuscript met the ICMJE recommendation for biomedical papers.

Redakční rada potvrzuje, že rukopis práce splnil ICMJE kritéria pro publikace zasílané do biomedicínských časopisů.

$\equiv$

Rodrigo Kraft Rovere, MD

Department of Medical Oncology

Santo Antonio Hospital

Rua Itajai 545

Blumenau, Santa Catarina

89020-000

Brazil

e-mail: rodrigorovere@hotmail.com

Submitted/Obdrženo: 8. 2. 2016

Accepted/Přijato: 17. 4. 2016

http://dx.doi.org/10.14735/amko2016274 


\section{Introduction}

Melanoma rates are increasing faster than any other malignancy in the world according to American and European sources $[1,2]$. In South America, the figures are not different, rising exponentially during the past years [3].

Even though many advances have been achieved lately in the field of metastatic melanoma [4-7], early diagnosis and appropriate surgical treatment remain critical to the cure.

The presence or absence of lymph node metastases is the most important prognostic factor for survival and recurrence in patients with cutaneous melanoma [8], leading to the development of a minimally invasive technique of lymph node assessment. This technique consists in sampling the first nodes on the most likely path of lymphatic spread of a primary cutaneous melanoma i.e., the sentinel lymph node (SLN) [9]. It has been shown by Morton et al. over 20 years ago that melanoma rarely metastasize to other nodules skipping the SLN [10]. Different surgical techniques may be performed and different tracers can be used, according to the surgeon's expertise [11]. This is a highly effective surgical procedure and maps the SLN in $98 \%$ of the times. If a positive SLN (PSLN) is detected, a surgical lymphadenectomy is then performed, according to the drainage area.

Lymphatic mapping has then become standard of care in most melanoma specialized centers in the world [12]. Clear prognostic information is obtained by this procedure, as a positive lymph node detection automatically places the disease in stage III. SLN commitment is strongly related to survival and recurrence rates and is a prognostic tool even in thick melanoma patients [13].

Nevertheless, some experts believe that the cost benefit ratio is not enough to advocate the procedure. A study comprising more than 2,000 patients fell short of displaying any survival benefit in five years [14]. The lack of an available active adjuvant treatment increases criticism of this method that does not lack complications, such as lymphedema, lymphocele and a calculated $96 \%$ rate of patients undergoing the SLN biopsy unnecessarily $[15,16]$.
On the other hand, some authors have suggested an improvement in overall disease-free survival rates [17]. Also, it is well known that patients with micrometastasis show better survival rates than those with macroscopic involvement. Nevertheless, randomized clinical trials failed to demonstrate significant survival rates in patients that underwent lymphadenectomy after SLN detection.

In spite of all the controversies regarding the issue, the procedure is still recommended for melanoma whose thickness is more than $1 \mathrm{~mm}$ according to European cancer guidelines [18].

The objective of our study is to assess the epidemiologic profile of patients who underwent SLN biopsy in Blumenau - Santa Catarina, Brazil. This is the city with the highest melanoma rates in Brazil, according to a previous study conducted by Naser [3], in a Brazilian region that has melanoma incidences over ten times more frequent than the mean rates of the country [19]. Pathologic characteristics, demographic variables and the specific characteristics of patients with positive nodes are also discussed.

\section{Methods}

Data was assembled from 62 consecutive patients who underwent surgery from 2003 to the early months of 2015. The population is largely composed of people with European genetic background, as expected in this Brazilian region [20].

Data has been retrieved retrospectively from patients electronic charts. In case of missing data, we have reviewed directly the anatomical-pathological original report in order to be as accurate as possible.

\section{Results}

Data are summarized in Tab. 1 and 2.

In the negative SLN (NSLN) group, there was a predominance of female patients $59.3 \%$. On the other hand, in the PSLN group, most patients were males (75\%). Nevertheless, this difference was not statistically significant (Tab. 1).

The primary lesion was most frequently found on the thorax in both positive and negative groups (Tab. 1).
As for the histopathological subtype, superficial spreading melanoma was more commonly found in the NSLN group $(66.7 \%)$, while nodular melanoma prevailed in the PSLN group (62.5\%) (Tab. 1). When we grouped the subtypes, nodular melanoma was significantly associated with positivity in SLN $(p=0.00126)$ than all the other subtypes together (Tab. 2).

Measurements of Breslow index were tested for normality, and by the Shapiro-Wilk test, the normality of each group was not confirmed. Therefore, a nonparametric test was performed - Mann-Whitney test. In this case, it showed that there are significant differences between the groups and the positive group showed a mean (or median in the case of this test) Breslow thickness significantly higher where $D Q$ is the quartile deviation. While the median for the NSLN group was $1.25 \pm 0.74$, the same measure for PSLN group was $3.5 \pm 2.45$; $\mathrm{p}=0.00022$ (Tab. 1, 2).

As for Clark levels, a level IV Clark level was associated with a positivity in SLN status, although the other levels were not $(p=0.0257)$ (Tab. 2). Breslow thickness correlates with metastatic affection of sentinel lymph node, meaning that thicker melanomas correlate with positivity of the exam. Nevertheless, in this study, Clarck V was not correlated with positivity in the SLN status. This might be explained by the low number of patients with this measurement in NSLN (only 1) and none in PSLN group.

Although regression was not associated with lymph node status in the present study, ulceration was marginally associated with this feature $(p=0.05)$ (Tab. 1).

\section{Discussion}

Even though we would have expected many more patients in this sample, a few setbacks must be stated. First, as explained above, given the fact that the SLN biopsy is not associated with survival benefit, many physicians in the multidisciplinary teams, such as dermatologists, oncologists and cancer surgeons, do not indicate the procedure. Second, as the vast majority of Brazilian patients do not have private health insurance and the 
Tab. 1. Demographic characteristics of the patients.

\begin{tabular}{|c|c|c|c|c|c|c|c|}
\hline \multirow[b]{2}{*}{ Factors } & \multicolumn{2}{|c|}{ Sentinel lymph node } & \multirow[b]{2}{*}{$\mathbf{p}$} & \multirow[b]{2}{*}{ Factors } & \multicolumn{2}{|c|}{ Sentinel lymph node } & \multirow[b]{2}{*}{$\mathbf{p}$} \\
\hline & $\begin{array}{c}\text { negative } \\
(\mathrm{n}=54)\end{array}$ & $\begin{array}{l}\text { positive } \\
(n=8)\end{array}$ & & & $\begin{array}{c}\text { negative } \\
(n=54)\end{array}$ & $\begin{array}{c}\text { positive } \\
(n=8)\end{array}$ & \\
\hline \multicolumn{8}{|l|}{ Gender } \\
\hline female & $32(59.3 \%)$ & $2(25 \%)$ & 0.0753 & \multirow{2}{*}{$\begin{array}{l}\text { superficial spreading, } \\
\text { radial growth phase }\end{array}$} & \multirow{2}{*}{$1(1.9 \%)$} & \multirow{2}{*}{$0(0 \%)$} & \\
\hline \multirow[t]{2}{*}{ male } & \multirow{3}{*}{$22(40.7 \%)$} & \multirow{3}{*}{$6(75 \%)$} & & & & & \\
\hline & & & & nodular phase & $1(1.9 \%)$ & $0(0 \%)$ & \\
\hline \multicolumn{2}{|l|}{ Local [1] } & & & lentigo maligno & $1(1.9 \%)$ & $0(0 \%)$ & \\
\hline head and neck & $10(19.2 \%)$ & $1(12.5 \%)$ & & invasive, VG phase & $1(1.9 \%)$ & $0(0 \%)$ & \\
\hline upper limbs & $9(17.3 \%)$ & $0(0 \%)$ & & \multirow{2}{*}{$\begin{array}{l}\text { nodular with } \\
\text { fusocelullar component, } \\
\text { VG phase }\end{array}$} & \multirow{2}{*}{1 (1.9\%) } & \multirow{2}{*}{$0(0 \%)$} & \\
\hline lower limbs & $11(21.2 \%)$ & $2(25 \%)$ & & & & & \\
\hline thorax & $21(40.4 \%)$ & $5(62.5 \%)$ & & \multirow{2}{*}{$\begin{array}{l}\text { desmoplastic, positive } \\
\text { margins }\end{array}$} & \multirow[b]{2}{*}{$1(1.9 \%)$} & \multirow[b]{2}{*}{$0(0 \%)$} & \\
\hline torsum and upper limb & $1(1.9 \%)$ & $0(0 \%)$ & & & & & \\
\hline \multicolumn{4}{|l|}{ Local [2] } & not informed & $4(7.4 \%)$ & $0(0 \%)$ & \\
\hline axilla & $12(22.2 \%)$ & $1(12.5 \%)$ & & \multirow{5}{*}{ Breslow } & \multirow{5}{*}{$\begin{array}{c}\text { (median } \pm \\
\pm \mathrm{DP})= \\
(1.71 \pm 1.34) \\
(\text { median } \pm \\
\pm \mathrm{DQ})= \\
(1.25 \pm 0.74)\end{array}$} & \multirow{5}{*}{$\begin{array}{c}\text { (median } \pm \\
\pm \mathrm{DP})= \\
(5.33 \pm 3.34) \\
(\text { median } \pm \\
\pm \mathrm{DQ})= \\
(3.5 \pm 2.45)\end{array}$} & \multirow{5}{*}{0.00022} \\
\hline inguinal & $10(18.5 \%)$ & $3(37.5 \%)$ & & & & & \\
\hline right axilla & $4(7.4 \%)$ & $2(25 \%)$ & & & & & \\
\hline left axilla & $5(9.3 \%)$ & $0(0 \%)$ & & & & & \\
\hline cervical & $6(11.1 \%)$ & $0(0 \%)$ & & & & & \\
\hline bilateral axilla & $4(7.4 \%)$ & $1(12.5 \%)$ & & & & & \\
\hline right inguinal & $3(5.6 \%)$ & $0(0 \%)$ & & Clark & & & \\
\hline supraclavicular & $2(3.7 \%)$ & $0(0 \%)$ & & I & $1(1.9 \%)$ & $0(0 \%)$ & \\
\hline neck & $0(0 \%)$ & $1(12.5 \%)$ & & II & $12(22.2 \%)$ & $0(0 \%)$ & \\
\hline right cervical & $1(1.9 \%)$ & $0(0 \%)$ & & III & $18(33.3 \%)$ & $2(25 \%)$ & \\
\hline parotideal & $1(1.9 \%)$ & $0(0 \%)$ & & IV & $15(27.8 \%)$ & $6(75 \%)$ & \\
\hline cervical bilateral & $1(1.9 \%)$ & $0(0 \%)$ & & V & $1(1.9 \%)$ & $0(0 \%)$ & \\
\hline inguinal and axilla & 1 (1.9\%) & $0(0 \%)$ & & $\| / I I$ & $1(1.9 \%)$ & $0(0 \%)$ & \\
\hline cervical and left axilla & $1(1.9 \%)$ & $0(0 \%)$ & & NA & $3(5.6 \%)$ & $0(0 \%)$ & \\
\hline parotideal and cervical & $1(1.9 \%)$ & $0(0 \%)$ & & not informed & $3(5.6 \%)$ & $0(0 \%)$ & \\
\hline left axilla and left inguinal & $1(1.9 \%)$ & $0(0 \%)$ & & & & & \\
\hline not informed & $1(1.9 \%)$ & $0(0 \%)$ & & Regression & & & \\
\hline & & & & no & $39(72.2 \%)$ & $8(100 \%)$ & 0.1640 \\
\hline Type & & & & yes & $11(20.4 \%)$ & $0(0 \%)$ & \\
\hline superficial spreading & $36(66.7 \%)$ & $3(37.5 \%)$ & & NA & $1(1.9 \%)$ & $0(0 \%)$ & \\
\hline nodular & $4(7.4 \%)$ & $5(62.5 \%)$ & & not informed & $3(5.6 \%)$ & $0(0 \%)$ & \\
\hline lentigo & $1(1.9 \%)$ & $0(0 \%)$ & & Ulcoration & & & \\
\hline NA (shaving) & $1(1.9 \%)$ & $0(0 \%)$ & & Uiceration & & & \\
\hline acral VG & $1(1.9 \%)$ & $0(0 \%)$ & & no & 37 (68.5\%) & $3(37.5 \%)$ & 0.0500 \\
\hline lentiginous & $1(1.9 \%)$ & $0(0 \%)$ & & yes & $13(24.1 \%)$ & $5(62.5 \%)$ & \\
\hline & & & & NA & $1(1.9 \%)$ & $0(0 \%)$ & \\
\hline & & & & not informed & $3(5.6 \%)$ & $0(0 \%)$ & \\
\hline $\begin{array}{l}\text { P value of Fischer's exact tes } \\
\text { To compare Breslow thickn } \\
\text { Observation one: From the } \\
\text { VG - vertical growth, NA }\end{array}$ & $\begin{array}{l}\text { in some case } \\
\text { ses Mann-Wh } \\
\text { patients on th } \\
\text { on evaluable }\end{array}$ & $\begin{array}{l}\text { it was not } p \\
\text { itney test } w \\
\text { e negative } \\
\text { DS - super }\end{array}$ & $\begin{array}{l}\text { ossible to } \\
\text { as perfor } \\
\text { rroup, se } \\
\text { icial diss }\end{array}$ & $\begin{array}{l}\text { ulate } p \text { value, because there } \\
\text { idn't present the Breslow th } \\
\text { ation, DP - standard deviati }\end{array}$ & $\begin{array}{l}\text { ere too many } f \\
\text { ckness mesure } \\
n, D Q-\text { quarti }\end{array}$ & $\begin{array}{l}\text { e. } \\
\text { ile deviation }\end{array}$ & nder 5. \\
\hline
\end{tabular}


Tab. 2. Factors associated with lymph node positivity.

\begin{tabular}{|c|c|c|c|}
\hline \multirow[t]{2}{*}{ Factors } & \multicolumn{2}{|c|}{ Sentinel lymph node } & \multirow{2}{*}{$\mathbf{p}$} \\
\hline & negative $(n=54)$ & positive $(n=8)$ & \\
\hline \multicolumn{4}{|l|}{ Type } \\
\hline nodular & 4 & 5 & 0.00126 \\
\hline others & 46 & 3 & \\
\hline \multicolumn{4}{|l|}{ Clark } \\
\hline IV & 15 & 6 & 0.0257 \\
\hline others & 33 & 2 & \\
\hline \multicolumn{4}{|l|}{ Clark } \\
\hline III or IV & 33 & 8 & 0.0672 \\
\hline others & 15 & 0 & \\
\hline
\end{tabular}

costs of the operation are not covered by the public health system, not many melanoma patients have access to the procedure, lowering expected figures.

Another interesting feature is that there are many differences in the anatomopathological descriptions of the primary lesions. This reflects the fact that they were analized by different pathologists, so a standardazation of this data could not be achieved.

One of the most important reasons for choosing not to perform the SLN biopsy in melanoma a few years ago was not only the lack of any spectacular benefit in adjuvant therapy but also the associated toxicities of this treatment [21]; moreover, very poor clinical results achieved by then standard chemotherapy in the advanced setting, i.e., once a patient was classified as high risk or even metastatic, the treating oncologist could do little to change the tumor natural history. However, as targeted therapy [22] and immunotherapy $[23,24]$ more and more grow in the field of melanoma, it is expected that one might be able to change the course of the disease by either selecting more appropriate patients to receive adjuvant treatment, as it is suggested in a subgroup analysis in a paper by Eggermont et al. [25]. Given the post hoc nature of the findings from the aforementioned paper, however, it is not to be taken as ultimate evidence but as hypothesis generating, deserving to be tested in prospective randomized trials with pre-planned ubgroup analysis.

Although controversies remain on whether or not to perform the procedure, most guidelines still support its indication. In order to lower the economical and physical impact, however, it would be a wise choice to try to determine which patients are more prone to present with a PSLN in the procedure and, perhaps, in the future, try to indicate the surgery to this particular group, which could benefit from further treatment options.

In the present paper, Breslow thickness, ulceration, nodular subtype and Clark level IV were associated with PSLN status. Further studies are necessary in order to determine if this particular group of patients will most benefit from the procedure.

\section{References}

1. Jemal A, Simard EP, Dorell C et al. Annual report to the nation on the status of cancer, 1975-2009, featuring the burden and trends in human papillomavirus (HPV)-associated cancers and HPV vaccination coverage levels. J Natl Cancer Inst 2013; 105(3): 175-201. doi: 10.1093/jnci/djs491.

2. Vranova J, Arenbergerova M, Arenberger P et al. Malignant melanoma in the Czech Republic: incidence and mortality according to sex, age and disease stage. Biomed Pap Med Fac Univ Palacky Olomouc Czech Repub 2014; 158: 438-446.

3. Naser N. Cutaneous melanoma: a 30-year-long epidemiological study conducted in a city in southern Brazil, from 1980-2009. An Bras Dermatol 2011; 86(5): 932-941.
4. Robert C, Thomas L, Bondarenko I et al. Ipilimumab plus dacarbazine for previously untreated metastatic melanoma. N Engl J Med 2011; 364(26): 2517-2526. doi: 10.1056/NEJMoa1104621.

5. Chapman PB, Hauschild A, Robert C et al. Improved survival with vemurafenib in melanoma with BRAF V600E mutation. N Engl J Med 2011; 364(26): 2507-2516.

6. Larkin J, Chiarion-Sileni V, Gonzalez R et al. Combined nivolumab and ipilimumab or monotherapy in untreated melanoma. N Engl J Med 2015; 373(1): 23-24. doi: 10.1056/NEJMoa1504030

7. Larkin J, Ascierto PA, Dreno B et al. Combined vemurafenib and cobimetinib in BRAF-mutated melanoma. N Engl J Med 2014; 371(20): 1867-1876. doi: 10.1056/NEJMoa1408868.

8. de Oliveira Filho RS, da Silva AM, de Oliveira DA et al. Sentinel node biopsy should not be recommended for patients with thick melanoma. Rev Col Bras Cir 2013; 40(2): 127-129.

9. Nicholl MB, Elashoff D, Takeuchi $H$ et al. Molecular upstaging based on paraffin-embedded sentinel lymph nodes: ten-year follow-up confirms prognostic utility in melanoma patients. Ann Surg 2011; 253(1): 116-122. doi: 10.1097/SLA.0b013e3181fca894

10. Morton DL, Wen DR, Wong JH et al. Technical details of intraoperative lymphatic mapping for early stage melanoma. Arch Surg 1992; 127(4): 392-399.

11. White I, Mills JK, Diggs B et al. Sentinel lymph node biopsy for melanoma: comparison of lymphocele rates by surgical technique. Am Surg 2013; 79(4): 388-392.

12. Faries M. Survival and the sentinel lymph node in melanoma. Ann Surg Oncol 2010; 17(1): 18-20. doi: 10.1245/s10434-009-0782-0.

13. Monroe MM, Pattisapu P, Myers JN et al. Sentinel lymph node biopsy provides prognostic value in thick head and neck melanoma. Otolaryngol Head Neck Surg 2015; 153(3): 372-378. doi: 10.1177/0194599815589 948.

14. Morton DL, Thompson JF, Cochran AJ et al. Sentinel-node biopsy or nodal observation in melanoma. N Engl J Med 2006; 355(13): 1307-1317.

15. Printz C. Physicians differ on the use of sentinel lymph node biopsy for melanoma: published data receive various interpretations. Cancer 2013; 119(14): 2515-2516. doi: $10.1002 /$ cncr.28229. 
16. Torjesen I. Sentinel node biopsy for melanoma: unnecessary treatment? BMJ 2013; 346: e8645. doi: 10.1136/ bmj.e8645.

17. Moncayo VM, Aarsvold JN, Alazraki NP. Lymphoscintigraphy and sentinel nodes. J Nucl Med 2015; 56(6): 901-907. doi: 10.2967/jnumed.114.141432.

18. Dummer R, Hauschild A, Guggenheim M et al. Melanoma: ESMO clinical practice guidelines for diagnosis, treatment and follow-up. Ann Oncol 2010; 21 (Suppl 5): v194-v197. doi: 10.1093/annonc/mdq188.

19. Lima AS, Stein CE, Casemiro KP et al. Epidemiology of melanoma in the South of Brazil: study of a city in the Vale do Itajai from 1999 to 2013. An Bras Dermatol
2015; 90(2): 185-189. doi: 10.1590/abd1806-4841.20153 076.

20. Kraft Rovere R, Colchon PH, Rebello JR. Adjuvant! Online: mind the gap! Klin Onkol 2013; 26(2): 110-113. doi: 10.14735/amko2013110.

21. Sondak VK, Wong SL, Gershenwald JE et al. Evidence-based clinical practice guidelines on the use of sentinel lymph node biopsy in melanoma. Am Soc Clin Oncol Educ Book 2013; 33: e320-e325. doi: 10.1200/EdBook_AM.2013.33.e320. 22. Robert C, Karaszewska B, Schachter J et al. Improved overall survival in melanoma with combined dabrafenib and trametinib. N Engl J Med 2015; 372(1): 30-39. doi: 10.1056/NEJMoa1412690.
23. Robert C, Schachter J, Long GV et al. Pembrolizumab versus ipilimumab in advanced melanoma. N Engl J Med 2015: 372(26): 2521-2532. doi: 10.1056/NEJMoa1503 093

24. Wolchok JD, Kluger H, Callahan MK et al. Nivolumab plus ipilimumab in advanced melanoma. N Engl J Med 2013; 369(2): 122-133. doi: 10.1056/NEJMoa1302369. 25. Eggermont AM, Suciu S, Testori A et al. Long-term results of the randomized phase III trial EORTC 18991 of adjuvant therapy with pegylated interferon alfa- $2 b$ versus observation in resected stage III melanoma. J Clin Oncol 2012; 30(31): 3810-3818. doi: 10.1200/JCO.2011.41. 3799.

\section{SOUTĚž NA PODPORU AUTORSKYYCH TÝMŮ PUBLIKUJÍCICH V ZAHRANIČNÍCH ODBORNÝCH TITULECH}

\section{Odměna pro vítěze: 10000 Kč}

\section{Cil soutěže:}

Podpořit renomé a prestiž časopisu Klinická onkologie - oficiálního časopisu ČOS ČLS JEP - u domácích i zahraničních autorů, lékařů a akademických pracovníků.

\section{Podmínky soutěže:}

1. Soutěž je určena autorským týmům, které publikují v zahraničních odborných titulech.

2. Do soutěže budou zařazeny práce publikované v zahraničních titulech od ledna do prosince 2016.

3. Ve svých článcích zaslaných k publikaci do zahraničního periodika budou autoři citovat práci, která byla otištěna v časopise Klinická onkologie (k vyhledání lze použít databáze www.pubmed.org nebo www.linkos.cz).

4. Do soutěže nebudou zařazeny autocitace.

5. Ze všech prací, které splní podmínky soutěže, bude redakční radou vylosována jedna, jejiž autorský tým bude oceněn částkou 10000 Kč.

\section{KLINICKÁ ONKOLOGIE

